\title{
Sinkholes risk analysis: case history of Marsala (Sicily, Italy)
}

\author{
V. Liguori, G. Manno \& V. Placenti \\ Dipartimento di Ingegneria Strutturale e Geotecnica, \\ Facoltà di Ingegneria, Università di Palermo Viale delle Scienze, \\ Palermo, Sicilia, Italia
}

\begin{abstract}
Given the increasing phenomenon of Sinkholes all over Italy, the Gruppo Nazionale per la Difesa dalle Catastrofi Idrogeologiche (G.N.D.C.I) and the Dipartimento della Protezione Civile (D.P.C.), during 2004, started a plan called Sinkholes dedicated to the phenomena in Italy. The plan provides the publication of the database realized by the D.P.C. by means of the census of beyond 1000 cases scattered across the nation. The city of Marsala is strongly characterized by the presence of a great number of Calcarenite cavities. The material object of extraction is the Calcarenite di Marsala of the Pleistocene, frequently used in the construction of buildings. The presence of the underground cavities in the city subsoil has in the last few decades caused a series of landslides whose frequency has visibly increased. The sinkholes have affected buildings and infrastructures. In the case of the evaluation of the hazard following the collapse of an underground cavity it is not possible to do probabilistic evaluations on the occurring events in a definite period. Such difficulty can be overcome if the concept of hazard is replaced with that of danger where no probabilistic term is included. In this context a methodology for the evaluation of the risk of Sinkholes proposes to foresee the identification of hazard expose areas and estimates the hazard $\mathrm{H}$ factor and potential damage $\mathrm{D}$ factor. Every factor will be given a weight, chosen inside of established classes of value. Through combination of the two factors, hazard $\mathrm{H}$ and potential damage $\mathrm{D}$, risk will be determined. The risk areas will be subdivided into zones with different degrees of exposure to the danger. In order to visualize and to localize the areas of interest by cavity and those already subject to landslides, a database has been realized, coordinated with a program GIS. Relatively to the areas subject to landslides, where possible, photographs, planimetries have been inserted and, in addition, a list has been compiled purposely proposed by the G.N.D.C.I and by the D.P.C.

Keywords: sinkholes, hazard, risk analysis.
\end{abstract}




\section{Introduction}

From the geologic point of view the lithotype prevalent in the Marsala territory is, in outcrop, the limestone facies of continental shelf, of early Pleistocene. The calcarenite, known as "Calcarenite di Marsala", is a tender rock, easy workable, frequently used in building construction, light yellow coloured with yellow or grey sand lens.

The territory of Marsala is strongly characterized by the presence of a very great number of Calcarenite cavities. The presence of the underground cavities (Liguori et al. $[1,2,3]$ ) in Marsala subsoil has in the last few decades caused a landslide series whose frequency has visibly increased (fig.1).

In the case of the evaluation of the hazard following the collapse of an underground cavity it is not possible to do probabilistic evaluations on the occurring events in a definite period. In this context a methodology for the evaluation of the sinkholes risk proposes to foresee the identification of hazard exposed areas and estimates the hazard $\mathrm{H}$ factor and potential damage $\mathrm{D}$ factor. Through combination of the two factors, hazard $\mathrm{H}$ and potential damage $\mathrm{D}$, risk will be determined. The risk areas will be subdivided into zones with different degrees of exposure to the danger.

Within the national project "Sinkholes" a database has been realized for the census of the phenomena in Marsala.

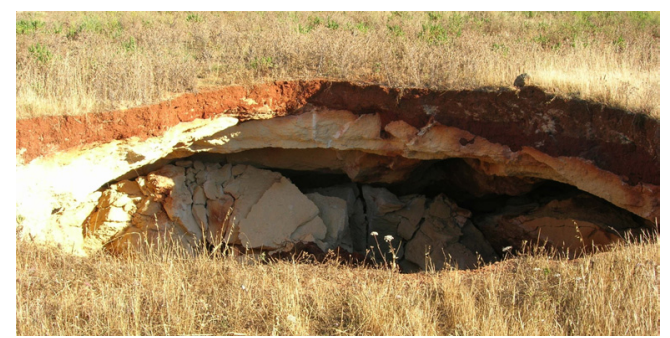

Figure 1: $\quad$ Sinkhole, June 2005.

\section{Typologies of cavities in Marsala}

The city of Marsala is situated at the south-western part of Sicily (I.G.M. 256 II NE "Marsala") (fig.2). For centuries, Calcarenite cavities, together with fishing and agriculture, have been a primary source of profit for the resident population from Campobello di Mazara to Marsala (Giordano [4]).

The cavities in the territory belong to two different typologies:

- open-pit quarry;

- gallery.

The open-pit quarry (fig.3), still used, is preferred because the superior layers offer the possibility of extraction of a stone with the ideal characteristics for 
building construction. The tenderness of the "Calcarenite di Marsala" allows one to directly obtain blocks that are ready for use. The use of this method has method has, unlike the gallery method, a great negative impact on the surrounding area.

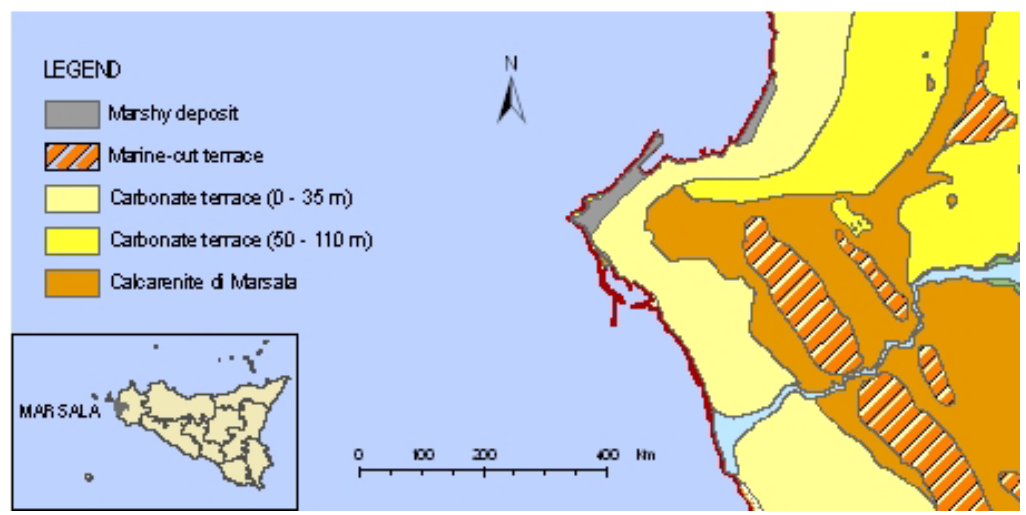

Figure 2: Marsala geology.

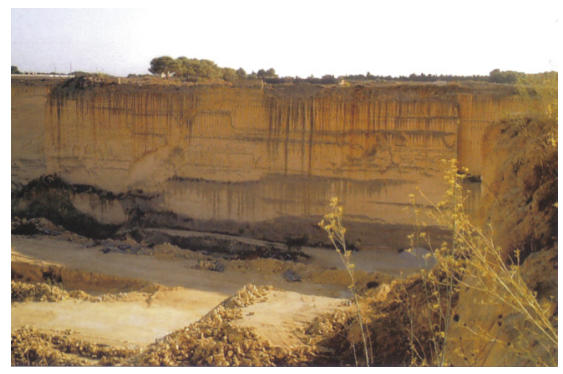

Figure 3: Typology of “open-pit” cavity.

The gallery method (fig.4), unlike the open-pit method, allowed a regular and continuous workmanship during whole year, also when climatic conditions were unfavourable; in this way there was the possibility to create an agricultural production of the soil, even if in limited measure.

The access to such galleries usually happened from open-pit quarry or through wells; the wells also served for the illumination, for the airing of the galleries, and for the removal of the blocks. The cavities of the zone were generally developed on two levels; the roofs, of varying thickness from $2 \mathrm{~m}$ to $14 \mathrm{~m}$, are today still sustained by pillars of quadrangular section that vary from more than $1 \times 1 \mathrm{~m}$ to $4 \times 4 \mathrm{~m}$. The pillars are characterized by the presence of frequent vertical incisions (fig.5) caused by the slicing-machine or, in smaller measure, from the axes (Spadaro et al. [5]).

The cavities, for the deserted sites, today represent a continuous source of collapse danger. The danger of the underground cavities is underlined by the 
events of the last forty years. There has been a significant progressive increase in these events in recent years (tab.1).

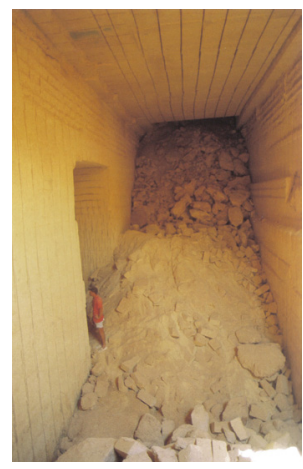

Figure 4: Underground passage. Figure 5: Underground pillar.

\begin{tabular}{|l|c|c|c|c|c|c|c|c|c|c|}
\hline Years & 1963 & 1975 & 1979 & 1995 & 1996 & 1997 & 1998 & 2003 & 2004 & 2005 \\
\hline N. events & 1 & 1 & 1 & 2 & 1 & 2 & 1 & 2 & 2 & 2 \\
\hline
\end{tabular}

\section{Risk analysis}

For the evaluation of the areas susceptible to landslide risk, the regulations issue for the procedures indicated in the "Atto di Indirizzo e Coordinamento" of the Decree of the President of the Council of the Ministers of September of 1998, in the Law 3 August 1998, n. 267 and in the UNESCO Report of Varnes and Iaeg (1984) (Assessorato Territorio e Ambiente Circolare 7 marzo 2003, n.1. [6]).

The methodology accounts for (in order of evaluation) the Intensity, the Hazard, the Damage and the final evaluation of the Risk.

Table 2: $\quad$ Matrix of intensity.

Table 3: Matrix of hazard.

\begin{tabular}{|c|c|c|c|c|}
\hline \multirow{2}{*}{ Area $\left(\mathrm{m}^{2}\right)$} & \multirow{2}{*}{$\begin{array}{c}\text { Volume } \\
\left(\mathrm{m}^{3}\right)\end{array}$} & \multicolumn{3}{|c|}{$\begin{array}{c}\text { Typology of } \\
\text { landslide }\end{array}$} \\
\cline { 3 - 5 } & $\mathrm{T}_{1}$ & $\mathrm{~T}_{2}$ & $\mathrm{~T}_{3}$ \\
\hline$<10^{4}$ & $<1$ & $\mathrm{I}_{1}$ & $\mathrm{I}_{2}$ & $\mathrm{I}_{3}$ \\
\hline $10^{4} \div 10^{5}$ & $>1$ & $\mathrm{I}_{2}$ & $\mathrm{I}_{3}$ & $\mathrm{I}_{4}$ \\
\hline $10^{5} \div 10^{6}$ & $>1$ & $\mathrm{I}_{2}$ & $\mathrm{I}_{3}$ & $\mathrm{I}_{4}$ \\
\hline$<10^{6}$ & $>1$ & $\mathrm{I}_{3}$ & $\mathrm{I}_{4}$ & $\mathrm{I}_{4}$ \\
\hline
\end{tabular}

\begin{tabular}{|l|c|c|c|c|}
\hline \multirow{2}{*}{\multicolumn{1}{|c|}{ State of activity }} & \multicolumn{4}{|c|}{ Intensity } \\
\cline { 2 - 5 } & $\mathrm{I}_{1}$ & $\mathrm{I}_{2}$ & $\mathrm{I}_{3}$ & $\mathrm{I}_{4}$ \\
\hline Stabilized & $\mathrm{H}_{0}$ & $\mathrm{H}_{0}$ & $\mathrm{H}_{0}$ & $\mathrm{H}_{1}$ \\
\hline Dormant & $\mathrm{H}_{0}$ & $\mathrm{H}_{1}$ & $\mathrm{H}_{1}$ & $\mathrm{H}_{2}$ \\
\hline Inactive & $\mathrm{H}_{1}$ & $\mathrm{H}_{1}$ & $\mathrm{H}_{2}$ & $\mathrm{H}_{3}$ \\
\hline Active or inactive & $\mathrm{H}_{1}$ & $\mathrm{H}_{2}$ & $\mathrm{H}_{3}$ & $\mathrm{H}_{4}$ \\
\hline
\end{tabular}

From the correlation between the intensity, obtained from table 2, and the state of activity, the indicative evaluation of the Hazard is obtained (tab.3). In table $2, \mathrm{~T}_{1}$ represents: run off, creep, lateral spreads, flow; $\mathrm{T}_{2}$ represents: 
complex landslide, flow slide, debris flow, mudslide; $\mathrm{T}_{3}$ represents: rockslide, falls, rapid mud flow. A Hazard scale is defined as follows: $\mathrm{H}_{0}$ low hazard, $\mathrm{H}_{1}$ moderate hazard, $\mathrm{H}_{2}$ middle hazard, $\mathrm{H}_{3}$ elevated hazard, $\mathrm{H}_{4}$ very elevated hazard.

Four classes of elements at risk have been identified, listed by increasing degree of vulnerability (tab.4). Through the combination of the two factors Hazard $(\mathrm{H})$ and risk elements $(\mathrm{E})(\mathrm{tab} .5)$, the risk is determined.

Table 4: Classification of the risk elements. Table 5: Matrix of the risk.

\begin{tabular}{|l|l|}
\hline \multicolumn{3}{|c|}{ Risk elements } \\
\hline E1 & $\begin{array}{l}\text { Areas with private and publics services. Sports facilities and } \\
\text { recreatives. Isolated houses. Agricultural development areas. } \\
\text { Cemetery. }\end{array}$ \\
\hline E2 & $\begin{array}{l}\text { Provincial and communal roads. Aqueducts, sewers, system of } \\
\text { depuration and system of refusals treatment. }\end{array}$ \\
\hline E3 & $\begin{array}{l}\text { Inhabited nucleus. Industrial installations. Installations of D.P.R n. } \\
175 / 88 . \text { Gas pipe-line, electric power line. Railway, highway. } \\
\text { Environment, cultural heritage (protect natural areas, areas binded to } \\
\text { the senses of law 1497 n. 439) }\end{array}$ \\
\hline E4 & Inhabited center \\
\hline
\end{tabular}

\begin{tabular}{|c|c|c|c|c|c|}
\hline & \multicolumn{4}{|c|}{ Risk elements } \\
\hline & & $E_{1}$ & $\mathrm{E}_{2}$ & $\mathrm{E}_{3}$ & $\mathrm{E}_{4}$ \\
\hline \multirow{5}{*}{ 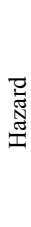 } & $\mathrm{H}_{0}$ & $\mathrm{R}_{1}$ & $\mathrm{R}_{1}$ & $\mathrm{R}_{1}$ & $\mathrm{R}_{\mathrm{l}}$ \\
\hline & $\mathrm{H}_{1}$ & $\mathrm{R}_{1}$ & $\mathrm{R}_{1}$ & $\mathrm{R}_{2}$ & $\mathrm{R}_{2}$ \\
\hline & $\mathrm{H}_{2}$ & $\mathrm{R}_{2}$ & $\mathrm{R}_{2}$ & $\mathrm{R}_{3}$ & $\mathrm{R}_{4}$ \\
\hline & $\mathrm{H}_{3}$ & $\mathrm{R}_{2}$ & $\mathrm{R}_{3}$ & $\mathrm{R}_{4}$ & $\mathrm{R}_{4}$ \\
\hline & $\mathrm{H}_{4}$ & $\mathrm{R}_{3}$ & $\mathrm{R}_{3}$ & $\mathrm{R}_{4}$ & $\mathrm{R}_{4}$ \\
\hline
\end{tabular}

The Law 3 August 1998, n.267, defines four classes of risk: Moderate $\mathrm{R}_{1}$, Middle $\mathrm{R}_{2}$, Elevated $\mathrm{R}_{3}$, Very much elevated $\mathrm{R}_{4}$.

Marsala has developed on the cavities, today the cavities are degradated and, in different zones, the roofs of the underground cavities are collapsed.

Trying to apply the methodology described before, it is observed that the typology of the sinkholes is not considered; however it's possible to link such phenomena to the falls for their sudden kinematics and for their destructive effects and because they are not foreseeable.

Therefore three possible situations are characterized.

Due to either a lack of or insufficiency of data, it has not been possible to attribute a determinable degree of Hazard $(\mathrm{Hc})$ and risk $(\mathrm{Rc})$ to all the areas potentially affected by cavities.

If, instead, by following precedents studies and reliefs of detail, there is an acceptable degree of sureness about the exact location and development of the underground cavities and about their actual state of degradation and consequent real falls danger, then the superficial areas will belong to very elevated class of hazard $\left(\mathrm{H}_{4}\right)$ and the existing assets will belong to a class of very elevated risk (risk much elevated) $\left(\mathrm{R}_{4}\right)$.

Likewise for those areas in which there are known and delimitated cavities, for which an opportune definitive consolidation has already been performed, the hazard and the risk will be considered null $\mathrm{H}_{0}$ and $\mathrm{R}_{0}$ (Corazza [7]).

\subsection{Proposal of risk analysis}

Here is an alternative methodology to appraise the sinkhole risk. The methodology considers the evaluation of the Hazard, the evaluation of the Damage and the final evaluation of the Risk. 


\subsubsection{Hazard evaluation}

In the evaluation of the hazard the intensity and the stability of the roof have a determining role; this last factor depends on the quality of the rock and particularly on the compression resistance, the spacing of the discontinuities, the condition of the joints and the presence of the water (Garbin et al. [8], Garzonio et al. [9]).

The instability phenomenon is characterized by a certain intensity. A valuation of the intensity of the phenomenon can be effectuated on the base of the volume been involved in the sinkholes (tab.6).

Table 6: $\quad$ Matrix of sinkholes' intensity.

\begin{tabular}{|c|c|c|c|}
\hline \multicolumn{2}{|c|}{} & Volume $\left(\mathrm{m}^{3}\right)$ & Description \\
\hline I1 & Moderate intensity & $<10^{2}$ & Isolated rock fall \\
\hline I2 & Middle intensity & $10^{2} \div 10^{4}$ & Limitated fall \\
\hline I3 & Elevated intensity & $10^{4} \div 10^{6}$ & Fall \\
\hline I4 & Very much elevated intensity & $>10^{6}$ & Catastrofic fall \\
\hline
\end{tabular}

Table 7: Numerical coefficients for the Bieniawski classification.

\begin{tabular}{|c|c|c|c|c|c|c|c|c|}
\hline \multirow{3}{*}{\begin{tabular}{c|} 
Parameters \\
\\
Rock \\
resistance
\end{tabular}} & \multicolumn{8}{|c|}{ Ranges of values } \\
\hline & \multirow{2}{*}{\begin{tabular}{|l} 
Point load (MPa) \\
$\begin{array}{l}\text { Monoaxial resistance } \\
(\mathrm{MPa})\end{array}$
\end{tabular}} & \multirow{2}{*}{$\begin{array}{l}>10 \\
>250\end{array}$} & \multirow{2}{*}{$\frac{4 \div 10}{100 \div 250}$} & \multirow{2}{*}{$2 \div 4$} & \multirow{2}{*}{$1 \div 2$} & \multicolumn{3}{|c|}{ Inapplicable } \\
\hline & & & & & & $5 \div 25$ & $1 \div 5$ & $<1$ \\
\hline \multicolumn{2}{|c|}{ Numerical coefficents } & 15 & 12 & 7 & 4 & 2 & 1 & 0 \\
\hline \multicolumn{2}{|l|}{ RQD (\%) } & $90 \div 100$ & $75 \div 90$ & $50 \div 75$ & $25 \div 50$ & \multicolumn{3}{|c|}{$<25$} \\
\hline \multicolumn{2}{|c|}{ Numerical coefficents } & 20 & 17 & 13 & 8 & \multicolumn{3}{|c|}{3} \\
\hline \multicolumn{2}{|c|}{ Joints Spacing (m) } & $>2$ & $0,60 \div 2$ & $0,6 \div 0,2$ & $0,06 \div 0,2$ & \multicolumn{3}{|c|}{$<0,06$} \\
\hline \multicolumn{2}{|c|}{ Numerical coefficents } & 20 & 15 & 10 & 8 & \multicolumn{3}{|c|}{5} \\
\hline \multicolumn{2}{|r|}{ Joints condition } & $\begin{array}{l}\text { Very rugged } \\
\text { surface, not } \\
\text { continous. } \\
\text { not altered } \\
\text { walls cliff }\end{array}$ & $\begin{array}{l}\text { Rugged } \\
\text { surface. } \\
\text { Opening < } \\
1 \mathrm{~mm} . \\
\text { Alterated } \\
\text { walls }\end{array}$ & $\begin{array}{l}\text { Rugged } \\
\text { surface. } \\
\text { Opening }<1 \\
\text { mm. Very } \\
\text { alterated } \\
\text { walls } \\
\end{array}$ & $\begin{array}{l}\text { Smooth or } \\
\text { laminated surface } \\
\text { o filling }<5 \mathrm{~mm} \\
\text { or apening of } 1 \div \\
5 \mathrm{~mm} . \text { Continous } \\
\text { joints }\end{array}$ & \multicolumn{3}{|c|}{$\begin{array}{l}\text { Tender filling }> \\
5 \mathrm{~mm} \text { or opening } \\
\text { joints }>5 \mathrm{~mm} . \\
\text { Continue joint. }\end{array}$} \\
\hline \multicolumn{2}{|c|}{ Numerical coefficents } & 30 & 25 & 20 & 10 & \multicolumn{3}{|c|}{0} \\
\hline \multirow{3}{*}{$\begin{array}{l}\text { Hydraulic } \\
\text { condition }\end{array}$} & $\begin{array}{l}\text { Leak of water for } 10 \mathrm{~m} \\
\text { of gallery }(1 / \mathrm{min})\end{array}$ & Absent & $<10$ & $10 \div 25$ & $25 \div 125$ & \multicolumn{3}{|c|}{$>125$} \\
\hline & $\begin{array}{l}\text { Relationship between } \\
\text { pressure of the water in } \\
\text { to joints and natural } \\
\text { pressure in site. }\end{array}$ & 0 & $<0,1$ & $0,1 \div 0,2$ & $0,2 \div 0,5$ & \multicolumn{3}{|c|}{$>0,5$} \\
\hline & General condition & Dry & Damp & Wet & Dripping & Wat & er flow & \\
\hline \multicolumn{2}{|c|}{ Numerical coefficents } & 15 & 10 & 7 & 4 & \multicolumn{3}{|c|}{0} \\
\hline
\end{tabular}

The Bieniawski (1979) methodology permits the user to value the stability of the inside walls of the hollow. The Bieniawski classification foresees the value of 5 parameters related to the condition of the rock and of an index of correction whose value is a function of the orientation of the discontinuity and the problem faced (galleries, slopes and foundations) [10]. The parameters are: 
1) compression resistance: obtained through the monoaxial crushing tests or through the Point Load Test;

2) RQD (Rock Qualità Designation): it represents the modified percentage of survey recovery. It is obtained from the relationship between the sum of the fragments of the core sample (having greater length of $10 \mathrm{~cm}$ ) and the total length of the core sample. When a continuous survey is not available the value of RQD can be estimated through the empiric equation: RQD $=(115-3,3 \mathrm{Jv})$ ( $\mathrm{Jv}$, discontinuity number for volume unit);

3) joints spacing;

4) joints condition: alteration, opening, persistence and filling;

5) hydraulic condition of the joints: expressed as relationship between the pressure of the water in to joints and the natural solicitations in site;

6) correction index.

Through an appropriate table (tab.7) it is attributed a numerical value to every parameter. Summing the values of the five parameters gives the "Basic RMR" (BRMR), a score of the rock quality. For the estimate of the index of correction Ic reference is made (tab. 8).

Table 8: $\quad$ Index of correction.

\begin{tabular}{|c|c|c|c|c|c|c|}
\hline \multicolumn{2}{|l|}{ Joints position } & $\begin{array}{c}\text { Very } \\
\text { favorable }\end{array}$ & Favorable & Discreet & Unfavorable & $\begin{array}{c}\text { Very } \\
\text { unfavorable }\end{array}$ \\
\hline Galleries, mines & \multirow{3}{*}{ 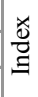 } & 0 & -2 & -5 & -10 & -12 \\
\hline Foundations & & 0 & -2 & -5 & -15 & -25 \\
\hline Slopes & & 0 & -5 & -7 & -50 & -60 \\
\hline
\end{tabular}

Applying the correction Ic to the BRMR is produces the index RMR, correlated to the quality of the rock and to its mechanical characteristics (tab. 9).

Table 9: Quality classes.

\begin{tabular}{|l|c|c|c|c|c|}
\hline RMR & $100 \div 81$ & $80 \div 61$ & $60 \div 41$ & $40 \div 21$ & $<20$ \\
\hline Class & I & II & III & IV & V \\
\hline Rock quality & Perfect & Good & Moderate & Poor & Very poor \\
\hline Cohesion (MPa) & $>0,4$ & $0,3 \div 0,4$ & $0,2 \div 0,3$ & $0,1 \div 0,2$ & $<0,1$ \\
\hline Friction angle & $>45^{\circ}$ & $35^{\circ} \div 45^{\circ}$ & $25^{\circ} \div 35^{\circ}$ & $15^{\circ} \div 25^{\circ}$ & $<15^{\circ}$ \\
\hline
\end{tabular}

Table 10: Matrix of hazard.

\begin{tabular}{|c|c|c|c|c|}
\hline \multirow{2}{*}{$\begin{array}{c}\text { Rock } \\
\text { classes }\end{array}$} & \multicolumn{4}{|c|}{ Intensity } \\
\cline { 2 - 5 } & $\mathrm{I}_{1}$ & $\mathrm{I}_{2}$ & $\mathrm{I}_{3}$ & $\mathrm{I}_{4}$ \\
\hline I & $\mathrm{H}_{0}$ & $\mathrm{H}_{1}$ & $\mathrm{H}_{2}$ & $\mathrm{H}_{2}$ \\
\hline II & $\mathrm{H}_{0}$ & $\mathrm{H}_{1}$ & $\mathrm{H}_{2}$ & $\mathrm{H}_{3}$ \\
\hline III & $\mathrm{H}_{1}$ & $\mathrm{H}_{1}$ & $\mathrm{H}_{2}$ & $\mathrm{H}_{3}$ \\
\hline IV & $\mathrm{H}_{1}$ & $\mathrm{H}_{2}$ & $\mathrm{H}_{3}$ & $\mathrm{H}_{3}$ \\
\hline V & $\mathrm{H}_{2}$ & $\mathrm{H}_{3}$ & $\mathrm{H}_{3}$ & $\mathrm{H}_{3}$ \\
\hline
\end{tabular}

Table 11: Hazard classes.

\begin{tabular}{|c|l|}
\hline $\mathrm{H}_{0}$ & Low hazard \\
\hline $\mathrm{H}_{1}$ & Moderate hazard \\
\hline $\mathrm{H}_{2}$ & Elevated hazard \\
\hline $\mathrm{H}_{3}$ & Very elevated hazard \\
\hline
\end{tabular}

It is possible, in this way, to characterize 5 classes of quality in which appear also the values of the friction angle and of the cohesion. 
From the correlation between the intensity and the quality of the rock it is possible to obtain an indicative evaluation of the hazard according to the scheme of tables 10 and 11 .

\subsubsection{Damage evaluation.}

The damage $\mathrm{D}$ expresses the consequences for the man in terms of human losses, material damages, loss of efficiency and functionality of infrastructures as a result of manifestation of an event. It is defined by the product of the risk elements for their vulnerability $\mathrm{V} ;(\mathrm{D}=\mathrm{E} \mathrm{V})$. The damage can be estimated with a simplified methodology that does not include the precise appraisal of the value of the risk elements and their vulnerability.

The analysis is carried out considering a schematic classification of the territory in homogeneous zones of urbanization and uses of the ground. For every zone the potential damage is foreseen in relation to the typology of risk element and to the intensity of the sinkhole. Four general classes of elements of risk are proposed which, arranged with the four classes of intensity defined in table 5, characterize four classes of potential damage (table 12 and 13).

Table 12: $\quad$ Matrix of damage.

\begin{tabular}{|c|l|c|c|c|c|}
\hline \multicolumn{2}{|c|}{ Risk elements } & \multicolumn{3}{|c|}{ Intensity } \\
\cline { 3 - 6 } \multicolumn{2}{|c|}{} & $\mathrm{I}_{1}$ & $\mathrm{I}_{2}$ & $\mathrm{I}_{3}$ & $\mathrm{I}_{3}$ \\
\hline $\mathrm{E}_{3}$ & $\begin{array}{l}\text { Town. Commercial and industrial settlements. Architectural property, historical } \\
\text { and artistic property. Railway, highway. }\end{array}$ & $\mathrm{D}_{2}$ & $\mathrm{D}_{3}$ & $\mathrm{D}_{3}$ & $\mathrm{D}_{3}$ \\
\hline $\mathrm{E}_{2}$ & Inhabited nucleus. Smaller commercial, industrial and handmade settlements. & $\mathrm{D}_{1}$ & $\mathrm{D}_{2}$ & $\mathrm{D}_{3}$ & $\mathrm{D}_{3}$ \\
\hline $\mathrm{E}_{1}$ & Isolated buildings. Rural zone, parks and pubblic gardens. & $\mathrm{D}_{1}$ & $\mathrm{D}_{1}$ & $\mathrm{D}_{2}$ & $\mathrm{D}_{3}$ \\
\hline $\mathrm{E}_{0}$ & Uninhabited or unproductive areas & $\mathrm{D}_{0}$ & $\mathrm{D}_{0}$ & $\mathrm{D}_{0}$ & $\mathrm{D}_{0}$ \\
\hline
\end{tabular}

Table 13: $\quad$ Classes of damage.

\begin{tabular}{|c|c|l|}
\hline \multicolumn{2}{|c|}{ Damage } & \multicolumn{1}{c|}{ Description } \\
\hline $\mathrm{D}_{0}$ & zero & no damage \\
\hline $\mathrm{D}_{1}$ & moderate & $\begin{array}{l}\text { superficial or functional damages on the buildings without to jeopardize the human } \\
\text { life and socio-economical activities }\end{array}$ \\
\hline $\mathrm{D}_{2}$ & medium & $\begin{array}{l}\text { Functional damages on the buildings. Occasional fires. Suspension of socio- } \\
\text { economical activities. }\end{array}$ \\
\hline $\mathrm{D}_{3}$ & elevated & $\begin{array}{l}\text { Serious functional damages on the buildings, possibility of dead and wounded, } \\
\text { descruction of socio-economical activities }\end{array}$ \\
\hline
\end{tabular}

\subsubsection{Risk evaluation}

Therefore through the combination of the hazard $\mathrm{H}$ and damage $\mathrm{D}$ the risk is determined. It is worthwhile to remember that risk, calculated in this way, cannot be considered in absolute terms. This means that if a situation results belong to a class of low risk, it doesn't mean that the situation is not risky in absolute terms but rather that, in a priority staircase, it is of inferior order in comparison to situations that belong to categories of high risk. The possible combinations between $\mathrm{H}$ and $\mathrm{D}$ are shown in table 14. The classes of risk were described before, $\mathrm{R}_{0}$ represents the lack of risk. 
Table 14: $\quad$ Matrix of risk.

\begin{tabular}{|c|c|c|c|c|c|}
\hline & \multicolumn{4}{|c|}{ Damage } \\
\hline & & $\mathrm{D}_{0}$ & $\mathrm{D}_{1}$ & $\mathrm{D}_{2}$ & $\mathrm{D}_{3}$ \\
\hline \multirow{4}{*}{ 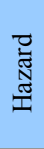 } & $\mathrm{H}_{0}$ & $\mathrm{R}_{0}$ & $\mathrm{R}_{0}$ & $\mathrm{R}_{0}$ & $\mathrm{R}_{0}$ \\
\hline & $\mathrm{H}_{1}$ & $\mathrm{R}_{0}$ & $\mathrm{R}_{1}$ & $\mathrm{R}_{1}$ & $\mathrm{R}_{2}$ \\
\hline & $\mathrm{H}_{2}$ & $\mathrm{R}_{0}$ & $\mathrm{R}_{1}$ & $\mathrm{R}_{2}$ & $\mathrm{R}_{3}$ \\
\hline & $\mathrm{H}_{3}$ & $\mathrm{R}_{0}$ & $\mathrm{R}_{2}$ & $\mathrm{R}_{3}$ & $\mathrm{R}_{3}$ \\
\hline
\end{tabular}

\section{Database}

Within the national project "Sinkholes" a database has been realized, coordinated with a program GIS, for the census of the sinkholes in Marsala and those yet to be included in the census. The GIS the ArchMap of the ESRI was used whose graphic interface consists of a Map display, a list of the layers present in the map, a toolbar and a series of menus. (Casagli et al. [11], Succhiarelli and Di Stefano [12]). The layers present in the map of the GIS "Sinkholes di Marsala" are: a group of I.G.M maps with a scale of 1:25000, a group of technical regional maps with a scale of 1:10000, the geology, the town limits, the roads, the railroads, the rivers, the urbanized areas, the sinkholes risk area and finally the layers of the cavities distinguished in open-pit quarry, gallery and sinkholes. Inside the GIS, a great amount of information can be associated to all the elements of the map, called "attributes". This information is stored in the Attributes table. For every fall photographs and planimetries have been inserted and a card compiled, purposely elaborated from the G.N.D.C.I. and from the D.P.C for the census of Sinkholes. The database allows easy visualization of all the collected information, selecting the specific sinkhole on the cartography. There are 12 sinkholes that have been included in the census; here we will consider two of the most recent and interesting events, information for the remaining collapses can be found in the database.

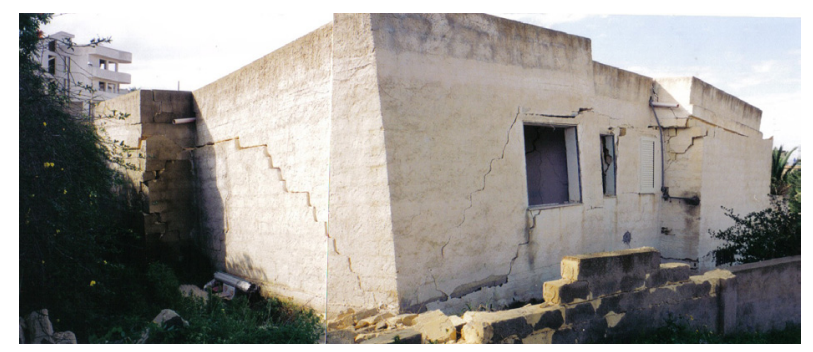

Figure 6: Building visibly damaged from the sinkhole.

In December of 1996, in the zone of "Timpone dell'Oro", a large section of the roof of the cavity suffered a lowering; a movement of rigid rotation of the whole block has followed. The collapse of Timpone dell'Oro caused serious 
damage in some buildings (fig.6). The area affected by the sinkhole has dimensions of 70x100m (Umiltà et al. [13]).

On 28th December 2003 at a distance of 2,480km from SS 188 occurred a sinkhole that affected the infrastructure. The sinkhole had an area of approximately $110 \mathrm{~m}^{2}$ and a depth of approximately $3,30 \mathrm{~m}$ (fig.7). The structure in figure 8 , visibly damaged, has been tilted solidly to the ground below.

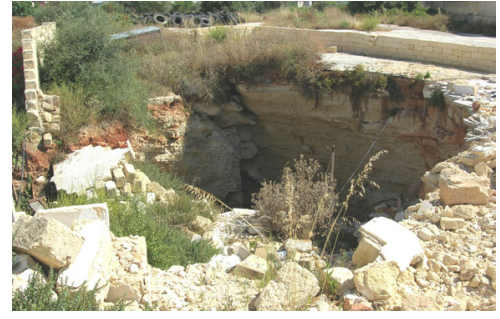

Figure 7: $\quad$ Sinkholes, 2003.

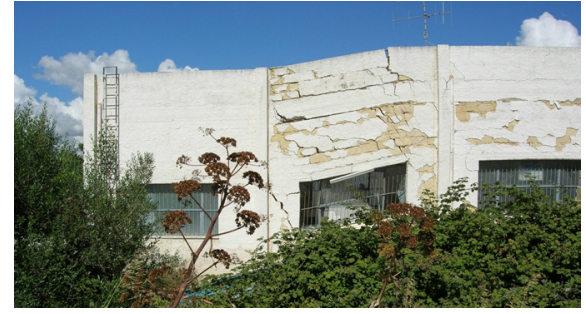

Figure 8: Damaged building.

Finally we are going to examine the sinkhole that occurred in May 2005 in the Amabilina zone. The sinkhole had a length of about $3200 \mathrm{~m}^{2}$ and a depth of $3 \mathrm{~m}$ (fig.9). The sinkhole caused the collapse of a residential area (fig.10).

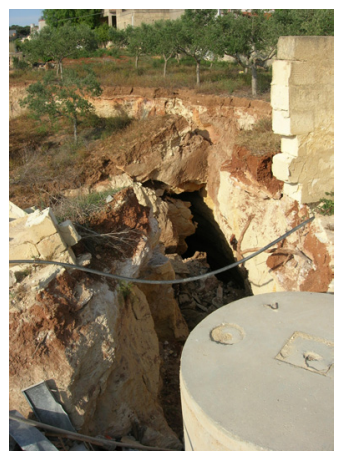

Figure 9: Perimetrical lesion.

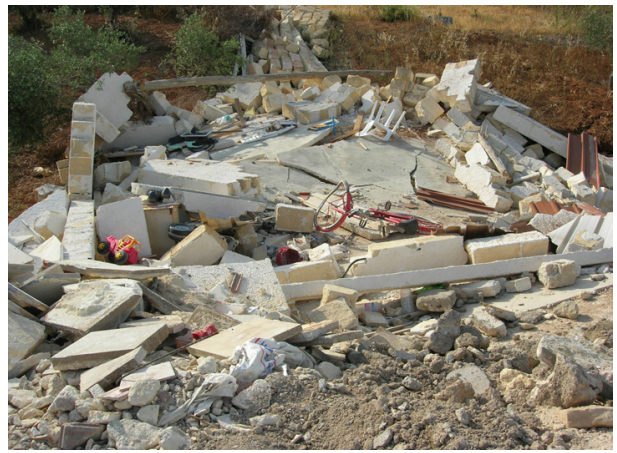

Figure 10: Sinkhole effects.

\section{Conclusions}

What emerges from this document is that the sinkholes in Marsala are a real problem that requires serious consideration, both in technical and institutional terms. It would be necessary to realize a program, also in the long term, for census of the cavities to pick up data about the exact location of the cavities, their geometry and the real conditions of stability. If the cavities have a known 
extension and they are exactly perimetrate, it would be possible to exclude the areas affected by new building.

Moreover, by picking up the needed information it would be possible to apply the methodology exposed in order to carry out a risk assessment from sinkhole to safeguard infrastructures and human life.

\section{References}

[1] Liguori V., Manno G., Mortellaro D. Rischio nelle aree carsiche in Sicilia: case history nella Piana di Cinisi (Palermo). Atti del Workshop: Stato dell'arte sullo studio dei fenomeni di sinkholes e ruolo delle amministrazioni statali nel governo del territorio. APAT Roma, 2004.

[2] Liguori V., Manno G., Nicastro G. Rischi nelle aree carsiche in Sicilia: Case Histories in aree carbonatiche ed evaporitiche. Atti del workshop G.N.D.C.I-C.N.R.: Conservazioni e difesa del Suolo Palermo, 2004.

[3] Liguori V., Manno G., Mortellaro D. Sixth International Conference on Geomorphology, Zaragoza Spagna. Special Session SS3 "Evaporite Karst ": relatore con un intervento su "Evaporitic karst in Sicily". 2005.

[4] Giordano T., L'equilibrio del vuoto: Marsala, le cave. Cave arte e cultura, Istituto Statale d'Arte di Palermo, pp. 61-63, 2004.

[5] Spadaro T., Donato G., Arini M., Lombardo V., Palermo M.G., Ingianni A., Paternò M., Marsala, Segni del territorio, Ed. Il Vomere. pp. 77-85, 2003.

[6] Assessorato Territorio e Ambiente, Circolare 7 marzo 2003, n.1.

[7] Corazza A. Il rischio di fenomeni di sprofondamento in Italia: le attività del dipartimento della protezione civile. Atti del Workshop: Stato dell'arte sullo studio dei fenomeni di sinkholes e ruolo delle amministrazioni statali nel governo del territorio. APAT Roma, 2004.

[8] Garbin F., Scarapazzi M., Cianci S., Cappelli G., Salvati R., Albanese G., Storoni S. Esempio di caratterizzazione geotecnica finalizzata alla definizione del rischio in un'area interessata da fenomeni di sprofondamento catastrofico (Tor Tre Ponti, Latina). Atti del Workshop: Stato dell'arte sullo studio dei fenomeni di sinkholes e ruolo delle amministrazioni statali nel governo del territorio. APAT Roma, 2004.

[9] Garzonio C. A., Barbuglia F., Iotti A. Le indagini e il monitoraggio di fenomeni di subsidenza e sprofondamento nell'area mineraria di Zavorrano (GR-Toscana). Atti del Workshop: Stato dell'arte sullo studio dei fenomeni di sinkholes e ruolo delle amministrazioni statali nel governo del territorio. APAT Roma, 2004.

[10] Classificazione dell'ammasso roccioso. www.programgeo.it/FormulaGeo Interpretazione $\% 20 \mathrm{di} \% 20$ rilievi $\% 20 \mathrm{di} \% 20$ meccanica $\% 20 \mathrm{delle} \% 20$ rocce. pdf

[11] Casagli N., De Rosa G., Fanti R., Moretti S. Il progetto Sinkholes del Gruppo Nazionale per la difesa dalle catastrofi idrogeologiche: Il censimento dei fenomeni sul territorio italiano. Atti del Workshop: Stato 
118 Risk Analysis V: Simulation and Hazard Mitigation

dell'arte sullo studio dei fenomeni di sinkholes e ruolo delle amministrazioni statali nel governo del territorio. APAT Roma, 2004.

[12] Succhiarelli C., Di Stefano V. Rilevamento di Sinkholes di origine antropica e interventi urbanistici nel territorio di monte delle piche (Roma sud-ovest). Stato dell'arte sullo studio dei fenomeni di sinkholes e ruolo delle amministrazioni statali nel governo del territorio. APAT Roma, 2004.

[13] Umiltà G., Umiltà P., Biancone V., Cave ipogee in aree urbane, XXI Convegno Nazionale di Geotecnica, L’Aquila, pp. 561-566, 2002. 